\title{
Desain Didaktis Konteks Fabel Berbasis Pemahaman Matematis Siswa pada Materi Aljabar
}

\author{
Surya Amami Pramuditya ${ }^{1 *}$, Muchamad Subali Noto $^{2}$, Via Dwi Handayani ${ }^{3}$ \\ ${ }^{1,2,3}$ Program Studi Pendidikan Matematika, Universitas Swadaya Gunung Djati \\ *amamisurya@gmail.com
}

\begin{abstract}
Abstrak
Penelitian ini dilatarbelakangi pentingnya pemahaman matematis siswa, tetapi faktanya pemahaman matematis siswa masih rendah dalam mengerjakan soal bentuk aljabar. Masalah tersebut memunculkan learning obstacle, yaitu siswa tidak bisa memaknai unsur-unsur bentuk aljabar serta tidak bisa mengoperasikan bentuk aljabar. Tujuan penelitian ini adalah merancang tahap desain didaktis menggunakan fabel berbasis pemahaman matematis siswa. Metode penelitian adalah deskriptif kualitatif dengan desain penelitian adalah Didactical Design Research (DDR) dengan subjek penelitian sebanyak 15 siswa SMP. Pengumpulan data dilakukan dengan teknik triangulasi, kemudian dianalisis secara deskriptif. Penelitian ini menghasilkan desain didaktis berupa situasi yang dapat mengantisipasi learning obstacle siswa dalam materi bentuk aljabar, serta memfasilitasi siswa dalam proses berpikir. Situasi dibuat dengan menggunakan gambar dan cerita yang menarik untuk memotivasi belajar siswa. Hasil menunjukan bahwa situasi-situasi yang telah dibuat, memudahkan siswa dalam mengelompokkan suku-suku sejenis dan tidak sejenis serta bisa mengoperasikan bentuk aljabar dengan mudah dan secara algoritma. Siswa juga mampu memaknai unsur-unsur bentuk aljabar berserta operasi penjumlahan dan pengurangan pada bentuk aljabar berdasarkan pemahaman siswa masing-masing.

Kata kunci: didactical design research, fabel, learning obstacles, pemahaman matematis
\end{abstract}

\begin{abstract}
This research is motivated by the importance of students 'mathematical understanding, but the fact is that students' mathematical understanding is still low in working on algebraic form questions. This problem brings out a learning obstacle, where students cannot interpret the algebraic form elements and cannot operate the algebraic form. This study aimed to design a didactic design phase using fables based on students' mathematical understanding. The research method is descriptive qualitative research. Design is Didactical Design Research (DDR) with 15 junior high school students as subjects. The data was collected using triangulation techniques, then analyzed descriptively. This study results in a didactic design in the form of a situation that can anticipate students' learning obstacles in algebraic form material and facilitate students' thinking process. Situations are created using exciting pictures and stories to motivate student learning. The results show that the situations that have been created make it easier for students to group similar and dissimilar terms and can operate the algebraic form easily and algorithmically. The students also can interpret the elements of the algebraic form along with addition and subtraction operations in the algebraic form based on the understanding of each student.
\end{abstract}

Keywords: didactical design research, fable, learning obstacles, mathematical understanding 


\section{Pendahuluan}

Pemahaman matematis merupakan aspek yang sangat penting untuk siswa dalam prinsip pembelajaran matematika (Mulyani, Indah \& Satria, 2018). Pentingnya pemahaman matematis yaitu untuk mencapai pembelajaran yang bermakna sehingga pembelajaran matematika harus diarahkan pada pengembangan kemampuan koneksi matematik antar ide, memahami ide-ide matematik saling terkait satu sama lain sehingga terbangun pemahaman menyeluruh, dan menggunakan matematik dalam konteks di luar matematika (NCTM, 2000). Oleh karena itu pemahaman matematis sangat penting untuk siswa dan akan lebih bermakna jika dibangun oleh siswa itu sendiri, artinya konsep-konsep matematika lebih mudah dimengerti dan tidak mudah terlupakan.

Namun berdasarkan kenyataan di lapangan, pemahaman matematis siswa masih sangat rendah. Hal ini didukung oleh Hidayat dan Sari (2019) yang menyatakan bahwa permasalahan yang berkaitan dengan mata pelajaran matematika sering muncul di tingkat Sekolah Menengah Pertama (SMP) hingga perguruan tinggi. Menurut Purwasih (2015), beberapa faktor penyebab dari rendahnya kemampuan pemahaman matematis siswa Indonesia, antara lain siswa terbiasa mempelajari konsep-konsep dan rumus-rumus matematika dengan cara menghafal tanpa memahami maksud, isi, dan kegunaannya. Salah satu materi yang memiliki pemahaman matematis yang rendah adalah materi aljabar pada jenjang SMP (House \& Telese, 2012; Awodun, Omotade, \& Adeniyi, 2013; Poon \& Leung, 2010). Beberapa penelitian juga menyatakan sulitnya pembelajaran aljabar di Indonesia (Jupri, Drijvers, \& Heuvel-Panhuizen, 2014; Maarif, 2016; Pratiwi, Herman, \& Lidinillah, 2017).

Bentuk aljabar banyak penerapannya dalam kehidupan sehari-hari dan juga penting untuk materi-materi yang lainnya (Hestenes, 1991). Sehingga siswa perlu menguasai konsep materi bentuk aljabar, dan siswa akan memiliki kemampuan memperoleh, mengelola, dan memanfaatkan informasi untuk dapat menyelesaikan masalah matematika dalam kehidupan sehari-hari. Namun, masih banyak siswa yang tidak bisa memahami operasi aljabar baik secara konsep, prinsip dan pengoperasian aljabar itu sendiri. Rendahnya kemampuan pemahaman matematis siswa dibuktikan dari hasil pekerjaan siswa terkait materi bentuk aljabar pada salah satu SMP di Kabupaten Cirebon, dimana soal kemampuan pemahaman matematis untuk pekerjaaan siswa tersebut diadopsi dari Noto, Pramuditya, dan Handayani (2020). Pemahaman siswa terhadap bentuk aljabar memerlukan pemahaman koefisien, variable dan konstanta terlebih dahulu.

Berdasarkan fakta observasi, siswa mendeskripsikan unsur-unsur bentuk aljabar menurut pemahamannya sendiri (intuisi). Dalam mendefinisikan koefisien dan konstanta 
sudah tepat jika menggunakan bahasa mereka sendiri sedangkan dalam mendefinisikan variabel, siswa mendefinisikannya dengan tidak tepat. Ketidaktepatan siswa menunjukkan bahwa siswa tidak memahami makna dari unsur-unsur bentuk aljabar itu sendiri khususya variabel. Siswa cenderung menyebutkan bahwa variabel adalah sebuah huruf. Dibenak mereka variabel itu huruf $x$ dan $y$. Hal ini selaras dengan penelitian Malihatuddarojah dan Prahmana (2019) bahwa kesulitan siswa dalam mempelajari aljabar terletak pada konsep dasar terkait unsur-unsur bentuk aljabar. Salah satu kesalahan siswa pada variabel bisa terjadi karena penggunaan bahan ajar dan metode yang kurang tepat selama proses pembelajaran (Badaruddin, Tengah, \& Prahmana, 2018). Padahal, sebagai pelajar mandiri mereka dituntut untuk mampu mencari, menemukan, dan memperdalam materi yang diterima melalui berbagai sumber belajar diantaranya adalah bahan ajar (Firmasari \& Pramuditya, 2018).

Fakta lainnya adalah siswa siswa dapat dikatakan kurang mampu dalam mengoperasikan bilangan bulat (bilangan bulat positif dengan bilangan bulat negatif hasilnya bilangan bulat negatif). Kemungkinan besar siswa salah dalam menentukan hasil operasinya, serta tidak menjawabnya dengan tepat. Lemahnya pemahaman siswa dalam konsep operasi bilangan bulat khususnya mengerjakan operasi penjumlahan atau pengurangan dengan suku bertanda negatif mengakibatkan hasilnya tidak tepat (Malihatuddarojah \& Prahmana, 2019). Hal ini menunjukkan bahwa terjadinya intervensi pemahaman yang dia peroleh saat mempelajari bilangan negatif (Booth, Barbieri, Eyer, \& Paré-Blagoev, 2014).

Fakta tersebut menunjukkan masih rendahnya kemampuan pemahaman matematis siswa pada materi bentuk aljabar, serta dapat disimpulkan bahwa siswa mengalami hambatan belajar (learning obstacle). Menurut Brousseau (2002) terdapat tiga tipe learning obstacle yaitu hambatan ontogeny (kesiapan mental belajar), didaktis (akibat pengajaran guru), dan epistemology (pengetahuan siswa yang memiliki konteks aplikasi yang terbatas).

Menurut Palpialy (2016), gagasan tentang learning obstacle terkait dengan kesulitan yang dialami oleh siswa dapat disebabkan dari beberapa sumber, diantaranya guru, materi ajar, dan siswa itu sendiri. Kedua gambar juga menunjukan bahwa siswa mengalami kesulitan dalam materi, yang artinya siswa memiliki hambatan belajar epistemology. Hal ini sejalan dengan penelitian Rahayu (2016), serta Putra, Nurwani, Putra, dan Putra (2017) yang dilakukan di salah satu SMP menyatakan bahwa rendahnya kemampuan siswa terhadap pembelajaran bentuk aljabar dalam menggunakan konsep dan prinsip aljabar.

Salah satu faktor meningkatkan pemahaman siswa dalam proses pembelajaran bentuk aljabar adalah kemampuan guru dalam mengembangkan suatu materi ajar (desain didaktis) (Morsanuto \& Cipollone, 2019). Sebelum proses pembelajaran dimulai, guru mempersiapkan 
desain didaktis sesuai dengan alur pembelajaran guna tercapainya tujuan pembelajaran. Desain didaktis merupakan rancangan pembelajaran berupa bahan ajar yang dibuat berdasarkan penelitian learning obstacle pada pembelajaran matematika yang telah muncul sebelumnya (Suryadi \& Nurelah, 2013).

Beberapa penelitian terkait desain didaktis telah dilakukan untuk meningkatkan kemampuan matematis siswa. Noto, Pramuditya, dan Fiqri (2018) dalam penelitiannya menghasilkan desain didaktis yang dapat menumbuhkan pemahaman matematis siswa pada materi limit. Sedangkan, Rosita, Nopriana, dan Silvia (2019) menghasilkan desain didaktis yang menumbuhkan kemampuan komunikasi pada materi lingkaran. Penelitian didaktis berorientasi untuk membangun perhatian dan kepedulian guru terhadap perkembangan siswa serta kehidupannya di masyarakat sebagai basis penentuan keputusan profesionalnya (Suratno, 2016). Oleh karena itu, desain didaktis dirancang dengan tujuan untuk mengatasi atau mengurangi learning obstacle yang muncul, agar siswa mampu memahami konsep suatu materi dalam matematika secara utuh.

Desain didaktis yang dirancang menggunakan cerita fabel. Fabel dipilih karena cerita ini digemari siswa di seluruh dunia (Prasetyo, 2014), sehingga dapat menjadi media yang menarik dalam rangka pembinaan karakter pada dunia pendidikan. Tujuan penelitian ini adalah merancang desain didaktis menggunakan fabel berbasis pemahaman matematis siswa, guna memudahkan siswa dalam mempelajari materi bentuk aljabar.

\section{Metode}

Metode Penelitian yang digunakan adalah deskriptif kualitatif dengan desain Didactical Design Research (DDR). Desain dibuat berdasarkan learning obstacle terkait materi aljabar (Noto, Pramuditya, \& Handayani, 2020). Tahapan penelitian meliputi analisis situasi didaktis dan analisis metapedadidaktik (Suryadi, 2013).

Pada tahap analisis situasi didaktis sebelum pembelajaran (prospective analysis), diberikan beberapa soal kemampuan pemahaman dan wawancara terkait materi bentuk aljabar. Selanjutnya, analisis learning obstacle dilakukan dengan mengaitkan alur pembelajaran yang dapat dikembangkan dengan membuat alur lintasan belajar yaitu urutan topik untuk materi bentuk aljabar. Setelah memetakan alur lintasan belajar tersebut, langkah selanjutnya terkait merancang desain didaktis dengan konteks yang digunakan adalah fabel. Setelah itu, selanjutnya dilakukan implementasi terhadap desain didaktis tersebut.

Penelitian ini dilakukan di salah satu SMP Negeri di Kabupaten Cirebon dengan partisipan sebanyak 15 siswa kelas VII yang terdiri atas empat laki-laki dan 11 perempuan 
dengan karakteristik memiliki nilai matematika yang heterogen. Pemilihan partisipan dilakukan secara purposive berdasarkan informasi dari guru kelas. Data dikumpulkan melalui triangulasi: observasi, tes, dan wawancara. Analisis data dilakukan secara deskriptif, yaitu secara manual menelaah setiap kata dan kalimat hasil observasi dokumen, tes, dan wawancara.

\section{Hasil Penelitian}

Analisis situasi didaktis dilakukan sebelum pembelajaran (prospective analysis), yaitu memberikan beberapa soal kemampuan pemahaman dan wawancara terkait materi bentuk aljabar, seperti: 1). Ungkapkan dengan bahasamu apa yang dimaksud dengan variabel, koefisien dan konstanta; 2). Sebutkan unsur-unsur bentuk aljabar dari bentuk $2 x+9$ ?; dan 3 ). Tentukan penjumlahan $16 a-12 b+4$ oleh $5 a-9 b+2 c, 4)$. Kurangkan $3 x+4 y$ dengan $5 x-6 y, 5)$. Sederhanakan bentuk aljabar $9 a^{2}+3 a b-7 b^{2}-12 a^{2}+6 a b+2 b^{2}$ !

Untuk menemukan jawaban soal kemampuan pemahaman tersebut diperlukan analisis struktur konsep bentuk aljabar agar dapat memetakan kesinambungan proses berpikir yang terlibat didalamnya. Hal ini mendasari pemetaan sajian materi ajar dari titik mana mulainya sampai titik akhirnya, serta bagaimana tahapan yang dilalui untuk mencapai tujuan pembelajaran (Maudy, 2015). Analisis learning obstacle dilakukan dengan mengaitkan alur pembelajaran yang dapat dikembangkan. Rangkaian proses tersebut disajikan pada Gambar 1 berikut.

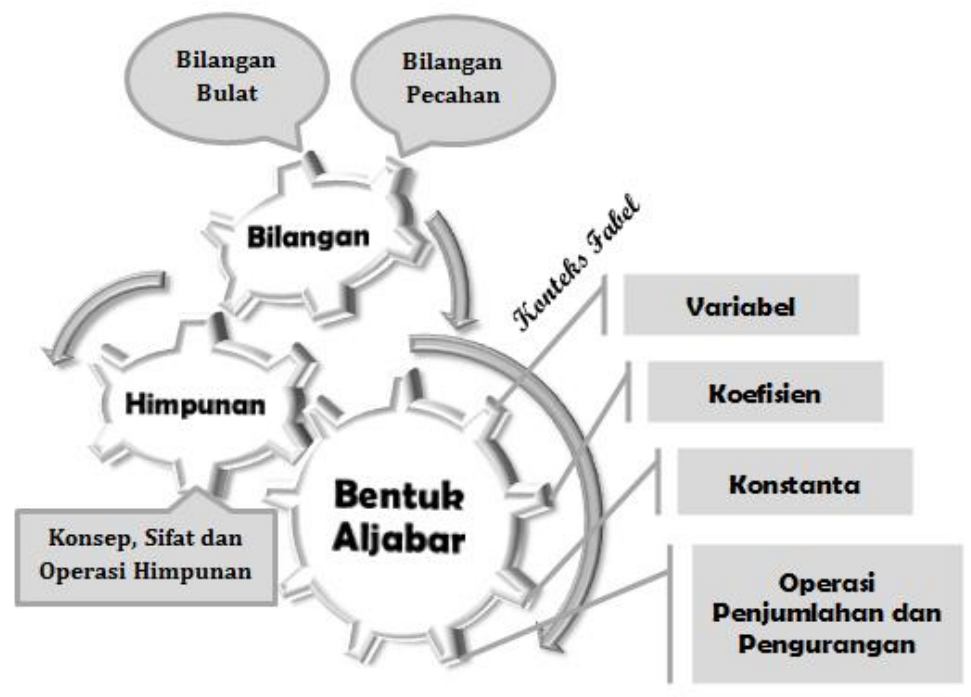

Gambar 1. Alternatif Alur Lintasan Belajar Materi Bentuk Aljabar 
Gambar 1 menunjukkan alur lintasan belajar untuk materi bentuk aljabar. Untuk memahami bentuk aljabar, siswa harus terlebih dahulu memahami bilangan dan himpunan. Berdasarkan hasil tes kemampuan pemahaman dan wawancara, learning obstacle yang ditemukan terkait ketidakbermaknaan variabel, koefisien dan konstanta serta terkait operasi penjumlahan dan pengurangan bentuk aljabar. Berikut salah satu contoh hasil tes. Diberikan soal "Ungkapkan dengan bahasamu apakah yang dimaksud dengan variabel, koefisien dan konstanta?". Pada soal tersebut, siswa diminta untuk mengungkapkan apa yang dimaksud dengan variabel, koefisien dan konstanta menurut pemahaman mereka masing-masing. Siswa menjawab soal tersebut sebagai berikut.

$$
\begin{aligned}
& \text { a. Koefesien }=\text { adalah angka yang memiliki variabel } \\
& \text { b. Konstanta }=\text { adalah angka yang tidak memiliki Variabe) } \\
& \text { c. Variabel }=\text { adalah huruf-huruf aljabar }(x, y)
\end{aligned}
$$

Gambar 2. Contoh Jawaban Tes Kemampuan Pemahaman

Setelah mendapatkan alur lintasan belajar, selanjutnya membuat desain didaktis dengan konteks yang digunakan adalah fabel. Berikut adalah desain didaktis terkait unsur-unsur bentuk aljabar. Permasalahan 1: "Seekor ayam boiler bertelur pada sarang yang sejenis. Hari pertama ia bertelur sebanyak 5 telur. Hari kedua ia bertelur sebanyak 5 telur. Hari ketiga ia bertelur sebanyak 5 telur. Berapakah total telur ayam yang dihasilkan selama 3 hari?" Gambar 3 menunjukkan bahwa siswa diminta untuk menghitung total telur secara keseluruhan selama tiga hari berturut-turut.

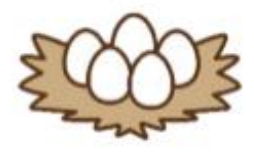

Hari ke-1

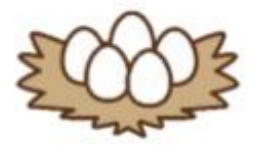

Hari ke-2

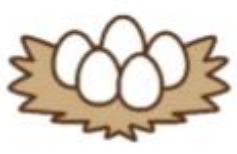

Hari ke-3

Gambar 3. Situasi Didaktis 1

Permasalahan 2: "Seekor ayam dan bebek bertelur pada sarangnya masing-masing. Hari pertama dan hari kedua, ayam bertelur sebanyak 5 telur sedangkan bebek bertelur sebanyak 4 telur. Berapakah total telur ayam dan telur bebek selama dua hari?" Gambar 4 menunjukkan bahwa siswa diminta untuk menghitung total telur ayam dan telur bebek selama dua hari berturut-turut. Dari situasi didaktis 1 dan 2, siswa diarahkan untuk menjawab soal dalam bentuk aritmetika bilangan dengan menghitung total telur ayam dan telur bebek di setiap sarangnya. 

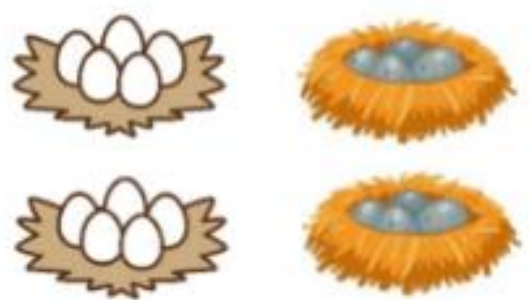

Hari ke-2

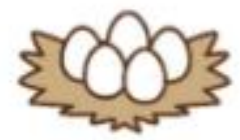

Gambar 4. Situasi Didaktis 2

Permasalahan 3: "Seekor ayam dan bebek bertelur dua hari berturut-turut pada sarangnya masing-masing. Jika kedua hari tersebut setiap sarang berisi telur ayam dan telur bebek yang sama banyak namun tidak diketahui berapa telur yang terisi. Berapakah total telur keseluruhannya?" Gambar 5 menunjukkan bahwa siswa diminta untuk menghitung total telur ayam dan telur bebek selama dua hari berturut-turut dimana mengarahkan anak dalam berpikir aljabar.

Hari ke-1
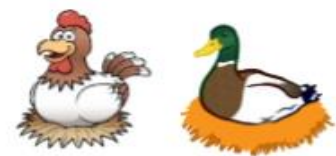

Hari ke-2

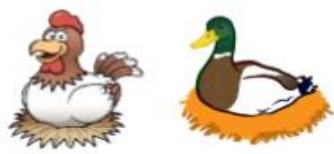

Gambar 5. Situasi Didaktis 3

Permasalahan 4: "Terdapat sarang ayam dan sarang bebek yang berisi telur, namun tidak diketahui berapa telur yang terisi. Apakah total telur ayam dan telur bebek sama?" Gambar 6 menunjukkan bahwa siswa diminta untuk membedakan variabel. Pada situasi didaktis 3 dan 4, siswa akan mengenal dan memaknai konsep variabel dalam bentuk aljabar.
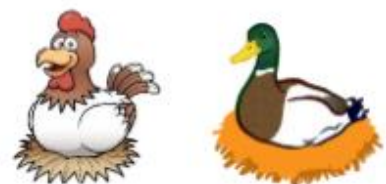

\section{Gambar 6. Situasi Didaktis 4}

Permasalahan 5: "Dari permasalahan ketiga terdapat sarang ayam dan sarang bebek. a) Ada berapa telur ayam? b) Ada berapa telur bebek?" Gambar 7 menunjukkan bahwa siswa diminta untuk menghitung ada berapa total telur ayam dan telur bebek selama dua hari berturut-turut. Pada situasi didaktis 5, siswa akan mengenal dan memaknai konsep koefisien dalam bentuk aljabar. 


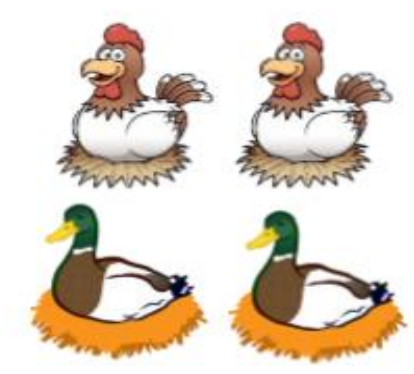

Gambar 7. Situasi Didaktis 5

Permasalahan 6: "Seekor ayam bertelur dua hari berturut-turut pada sarangnya masingmasing. Jika kedua hari tersebut setiap sarang berisi telur yang sama banyak namun tidak diketahui berapa telur yang terisi. Pada hari ketiga ia bertelur diluar sarang sebanyak 4 telur. Berapakah total telur ayam keseluruhan?" Gambar 8 menunjukkan bahwa siswa diminta untuk menghitung ada berapa total telur ayam dan telur bebek secara keseluruhan. Pada Situasi didaktis 6, siswa akan mengenal dan memaknai konsep variabel, koefisien dan konstanta dalam bentuk aljabar.

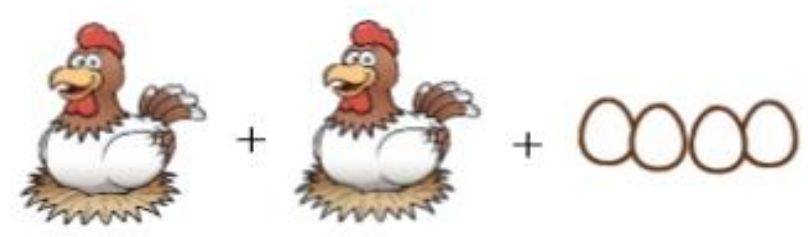

Gambar 8. Situasi Didaktis 6

Situasi didaktis 1 dan 2, menyajikan konteks fabel dalam menghitung total telur secara keseluruhan, dalam situasi ini siswa akan memahami aritmatika bilangan tentunya akan mengarahkan kedalam aritmetika bentuk aljabar. Situasi didaktis 3 dan 4, menyajikan konteks fabel dalam menghitung total telur yang belum diketahui nilainya, sehingga penulis memprediksi bahwa siswa akan mengubah sarang-sarang tersebut kedalam bentuk gambar maupun simbolik tentunya sudah mengenalkan konsep variabel bentuk aljabar. Situasi didaktis 5 dan 6, menyajikan konteks fabel dalam menghitung total telur yang belum diketahui nilainya secara keseluruhan, dalam situasi ini siswa akan memaknai konsep variebel, koefisien dan konstanta dalam bentuk aljabar. Setelah selesai membuat desain didaktis dengan enam situasi tersebut, maka dilakukan implementasi seperti Gambar 9 berikut. 


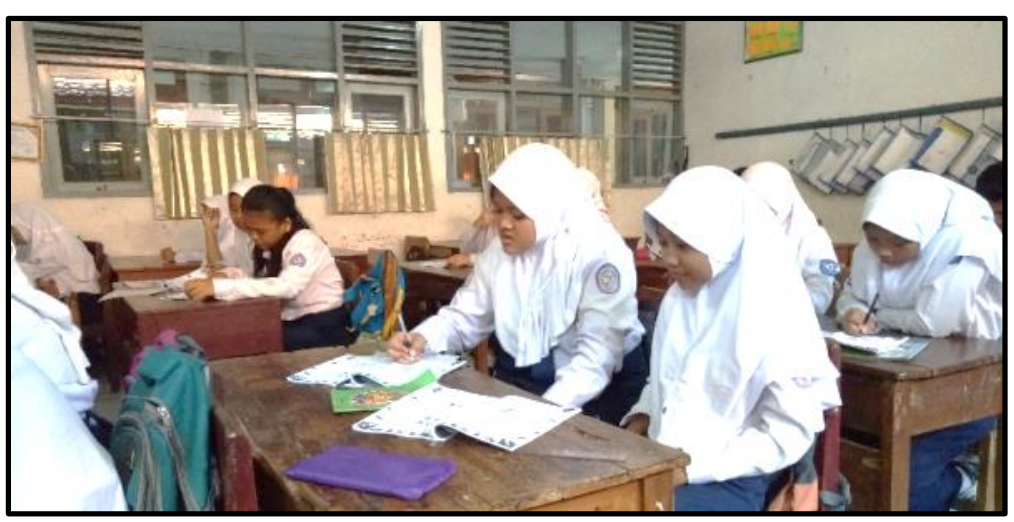

Gambar 9. Implementasi Desain Didaktis

Gambar 9 menunjukkan bahwa siswa sedang menyelesaikan permasalahan 1 sampai permasalahan 6 terkait unsur-unsur bentuk aljabar yang tersaji pada bahan ajar. Kegiatan implementasi memberikan kesesuaian hasil yang sama dengan prediksi peneliti bahwa siswa mengganti nilai yang tidak diketahui tersebut denggan menggunakan gambar, bentuk dan huruf yang beragam. Jawaban siswa disajikan dalam Tabel 1 sebagai berikut.

Tabel 1. Jawaban Siswa Permasalahan 1 - 6

\begin{tabular}{|c|c|c|}
\hline No & Jawaban Siswa & Banyak Siswa \\
\hline \multicolumn{3}{|c|}{ A. Permasalahan 1} \\
\hline & $\begin{array}{l}\text { Cara 1: } 5+5+5 \\
\text { Cara 2: } 3 \times 5\end{array}$ & 15 \\
\hline \multicolumn{3}{|c|}{ B. Permasalahan 2} \\
\hline 1. & Cara 1: $5+5+4+4$ & 5 \\
\hline 2. & Cara 2: $2 \times(5+4)$ & 3 \\
\hline 3. & Cara 3: $(2 \times 5)+(2 \times 4)$ & 7 \\
\hline \multicolumn{3}{|c|}{ C. Permasalahan 3} \\
\hline 1. & $2 \times$ & 2 \\
\hline & 3 \\
\hline 3. & $x+x+y+y=2 x+2 y$ & 10 \\
\hline \multicolumn{3}{|c|}{ D. Permasalahan 4} \\
\hline 1. & $\begin{array}{l}\text { Tidak, karena jenis telur dan sarangnya } \\
\text { berbeda }\end{array}$ & 11 \\
\hline 2. & $\begin{array}{l}\text { Tidak, karena ayam dan bebek bertelur } \\
\text { disarangnya masing-masing }\end{array}$ & 4 \\
\hline \multicolumn{3}{|c|}{ E. Permasalahan 5} \\
\hline & a. $2 \times$ & 5 \\
\hline
\end{tabular}




\begin{tabular}{ccc}
\hline No & Jawaban Siswa & Banyak Siswa \\
\hline & b. $2 \times$ & \\
\hline 2. & $\begin{array}{l}\text { a. } c+c=2 c \\
\text { b. } s+s=2 s\end{array}$ & 10 \\
\hline F. & Permasalahan 6 & \\
\hline 1. & $2 x+4$ & 2 \\
\hline 2. & $2 m+4$ & 5 \\
\hline 3. & $2 y+4$ & \\
\hline
\end{tabular}

Desain selanjutnya disusun dengan menyajikan permasalahan menggunakan konteks fabel terkait penjumlahan bentuk aljabar yang memungkinkan siswa untuk menyelesaikan permasalahan tersebut secara algoritma. Situasi didaktis terkait operasi penjumlahan dan pengurangan bentuk aljabar tersebut disajikan dalam soal permasalahan konteks fabel sebagai berikut.

Permasalahan 7: "Lila memiliki tiga ikat wortel sejumlah $x$ wortel, ia mendapat dua ikat wortel sejumlah $x$ wortel dan dua ikat bayam sejumlah $y$ bayam dari Lili. Berapa banyak wortel dan bayam yang dimiliki Lila?” Gambar 10 menunjukkan cerita binatang Lila dan Lili yang yang saling memberi ikat wortel dan ikat bayam yang belum diketahui nilainya, sehingga siswa diminta untuk menentukan berapa jumlah wortel dan bayam yang dimiliki Lila setelah dijumlahkan dengan pemberian dari Lili.

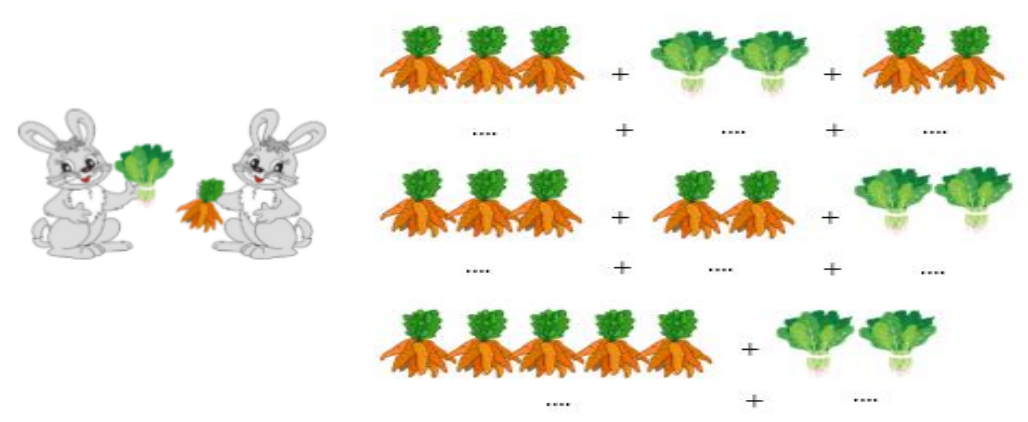

Gambar 10. Situasi Didaktis 7

Pada saat siswa diberi ruang untuk berpikir, masing-masing siswa mampu dalam menyelesaikan permasalahan tersebut sesuai prediksi penulis yaitu siswa menyelesaikannya dengan cara algoritma tentunya memahami konsep variabel serta suku sejenis dan tidak sejenis dalam bentuk aljabar. Hal ini disajikan dalam Tabel 2 berikut. 
Tabel 2. Jawaban Siswa Permasalahan 7

\begin{tabular}{|c|c|c|}
\hline No & Cara & Banyak Siswa \\
\hline A. & Melengkapi Tabel & \\
\hline 1. & $\begin{array}{l}3 x+2 y+2 x \\
3 x+2 x+2 y \\
5 x+2 y \\
\text { Sehingga banyaknya bayam dan wortel Lila } \\
\text { adalah dua kali banyaknya bayam perikat } \\
\text { ditambah lima kali banyaknya wortel perikat }\end{array}$ & 15 \\
\hline
\end{tabular}

Situasi didaktis selanjutnya terkait operasi penjumlahan dan pengurangan bentuk aljabar tersebut disajikan dalam soal permasalahan konteks fabel sebagai berikut. Permasalahan 8: "Kiki semut yang mungil memiliki empat kantong berisi gula yang sama banyak sejumlah $k$ dan lima kantong berisi biji-bijian yang sama banyak sejumlah $l$. Jika dua kantong berisi gula dan satu kantong berisi biji-bijian tersebut diberikan kepada Boni sang jangkrik pemalas, berapa sisa gula dan biji-bijian perkantong yang dimiliki Kiki?’

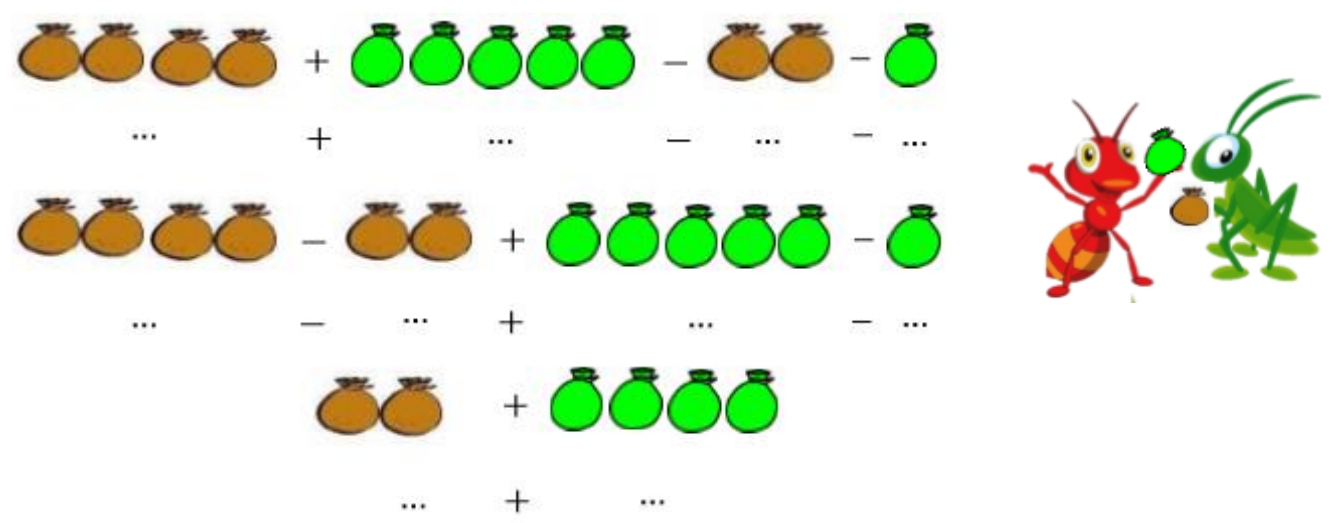

Gambar 11. Situasi Didaktis 8

Gambar 11 menunjukkan cerita binatang Kiki seekor semut yang baik hati dan Boni seekor Jangkrik pemalas. Kiki memberikan sedikit makanan miliknya untuk Boni sang jangkrik, sehingga siswa diminta untuk menentukan berapa jumlah sisa makanan yang dimiliki Kiki setelah diberikan kepada Boni.

Pada saat siswa diberi ruang untuk berpikir untuk menyelesaikan permasalahan tersebut, masing-masing siswa mampu dalam menyelesaikan permasalahan dengan memaknai bahwa sekantong gula dan sekantong biji-bijian yang belum diketahui nilainya dengan sebuah simbol sesuai dengan soal tersebut. Hal ini tersebut sesuai prediksi peneliti, yaitu siswa menyelesaikannya dengan cara algoritma tentunya memahami konsep variabel serta suku sejenis dan tidak sejenis dalam bentuk aljabar. Hal ini disajikan dalam Tabel 3 berikut. 
Tabel 3. Jawaban Siswa Permasalahan 8

\begin{tabular}{ccc}
\hline No & \multicolumn{1}{c}{ Cara } & Banyak Siswa \\
\hline A. Melengkapi Tabel & \\
\hline & $4 k+5 l-2 k-l$ \\
& $4 k-2 k+5 l-l$ \\
& $2 k+4 l$ & \\
$1 . \quad$ Sehingga banyaknya sisa makanan milik Kiki & 15 \\
& adalah 2 kali kantong berisi gula sebanyak $k$ & \\
& dan empat kali kontong berisi biji-bijian & \\
& sebanyak $l$ \\
\hline
\end{tabular}

Tabel 1, Tabel 2, dan Tabel 3 merupakan keberagaman respons siswa yang membuat mereka saling belajar, serta memahami satu sama lain dengan memerlukan bimbingan dari guru. Ketika guru memberikan mereka ruang untuk berpikir secara lebih mendalam, maka siswa mampu memikirkan ide-ide penyelesaian permasalahan-permasalahan terkait bentuk aljabar. Manfaat lainnya adalah siswa dapat berbagi informasi tersebut kepada temantemannya sehingga mereka membangun pengetahuan bersama.

\section{Pembahasan}

Hasil penelitian di atas dapat memberikan beberapa gambaran terhadap prediksi dan antisipasi guru dalam menciptakan pembelajaran yang baik di kelas, terutama saat materi aljabar. Antisipasi melalui situasi didaktis dapat menjadi komunikasi ruang berpikir antara guru dan siswa.

Dengan adanya ruang berpikir dan kerja sama selama proses pembelajaran, maka akan membangun minat belajar dan suasana menyenangkan bagi siswa sesuai dengan alur pembelajaran yang terkonsep. Terkait hal itu, setidaknya terdapat tiga hal yang perlu diperhatikan, yaitu aspek kesatuan, kesinambungan dan keluwesan sehingga ketiga dimensi tersebut mendasari daya tanggap guru terhadap kesesuaian serta ketidaksesuaian antara prediksi guru dan antisipasi pada saat perencanaan dengan kenyataan yang terjadi di kelas (Maudy, 2015). Sehingga, dengan adanya beragam respons siswa, penelitian desain didaktis ini mampu mengatasi learning obstacle siswa melalui situasi-situasi didaktis dalam konteks fabel tersebut.

Dilihat dari faktor biologis, siswa menengah pertama akan masuk ke dunia dewasa secara fisiologis, kognitif, penalaran moral, perkembangan psikoseksual, dan perkembangan social (Piaget, 1971). Masuknya siswa ke dunia dewasa maka siswa membutuhkan penanaman nilai moral (Rohman, 2016). Siswa membutuhkan sebuah cerita kehidupannya untuk dirinya sendiri yang biasanya disebut dengan personal fabel. Menurut Elkind (1974), 
menjelaskan personal fabel merupakan keyakinan remaja yang meyakini bahwa diri mereka tersebut adalah unik dan tidak terpengaruh oleh hukum alam. Artinya, keyakinan diri seseorang adalah unik dan memiliki karakteristik khusus yang hebat serta diyakini benar adanya tanpa menyadari sudut pandang orang lain dan fakta sebenarnya. Berdasarkan tabel yang tersaji, hal tersebut dibuktikan siswa melalui keberagaman respon jawaban mereka.

Siswa sebagai individu yang unik tentunya memiliki karakteristik yang berbeda-beda (Putri, 2020). Oleh karena itu, siswa mempunyai konsepsi awal yang berbeda-beda mengenai suatu hal. Konsepsi awal tersebut dapat memunculkan hambatan belajar untuk siswa dalam proses pembelajaran. Hambatan belajar itu sendiri merupakan hal yang wajar dalam proses pembelajaran. Hal ini terjadi karena setiap siswa mempunyai cara tersendiri dalam membangun dan membentuk pengetahuan yang sedang dipelajarinya (Stapleton, 2019). Hanya saja, guru sebaiknya dapat mengantisipasinya melalui situasi didaktis yang bisa saja selalu baru di setiap pembelajarannya.

Situasi-situasi didaktis yang disajikan sesuai dengan tahapan teori belajar Bruner (1977) yaitu tahap enaktif-ikonik-simbolik, dimana tahap tersebut melibatkan siswa dalam mengoperasikan bentuk aljabar dengan cara mengelompokkan suku-suku sejenis secara algoritma dalam konteks fabel. Situasi dibuat dengan menggunakan gambar-gambar yang menarik untuk memotivasi belajar siswa. Gambar tersebut tentunya mengarahkan pada konsep unsur-unsur bentuk aljabar terkait variabel, koefisien dan konstanta, seperti gambar seikat wortel sejumlah $x$, seikat bayam sejumlah $y$, sekantong berisi gula sejumlah $k$, sekantong berisi biji-bijian sejumlah $l$, dan gambar-gambar menarik lainnya.

Hasil menunjukan bahwa situasi-situasi yang telah dibuat, memudahkan siswa dalam mengelompokkan suku-suku sejenis dan tidak sejenis serta bisa mengoperasikan bentuk aljabar dengan mudah dan secara algoritma. Saat diimplementasikan, siswa dapat menyelesaikan operasi penjumlahan dan pengurangan bentuk aljabar dengan benar dan tepat. Hal tersebut sejalan dengan Van den Heuvel-Panhuizen (2009) yang menggunakan buku bergambar untuk mengembangkan proses berpikir matematika siswanya.

\section{Simpulan}

Desain didaktis menggunakan fabel berbasis pemahaman matematis siswa dapat mengantisipasi learning obstacle siswa dalam materi bentuk aljabar serta dapat memfasilitasi siswa dalam proses berpikir. Siswa mampu memaknai unsur-unsur bentuk aljabar berserta operasi penjumlahan dan pengurangan pada bentuk aljabar berdasarkan pemahaman masing- 
masing. Desain didaktis ini juga dapat digunakan oleh guru sebagai alternatif pembelajaran aljabar di kelas.

\section{Referensi}

Awodun, A., Omotade, O. J. O., \& Adeniyi, O. (2013). Mathematics skills as predictors of physics students' performance in senior secondary schools. International Journal of Science and Research, 2(7), 391-394.

Badaruddin, D. P., Tengah, K. A., \& Prahmana, R. C. I. (2018). Enhancing manipulation of algebraic equation through Balance Method. Journal of Physics: Conference Series, 1088(1), 012007. https://doi.org/10.1088/1742-6596/1088/1/012007.

Booth, J. L., Barbieri, C., Eyer, F., \& Paré-Blagoev, E. J. (2014). Persistent and pernicious errors in algebraic problem solving. The Journal of Problem Solving, 7(1), 10-23. https://doi.org/10.7771/1932-6246.1161.

Bruner, C. J. (1977). The processe of education. Cambridge: Harvard University Press.

Brousseau, G. (2002). Theory of didactical situations in mathematics: Didactique des mathématiques, 19, 1970-1990. Netherlands: Springer Science \& Business Media.

Elkind, D. (1974). Children and adolescents: Interpretive essays on Jean Piaget. England: Oxford U. Press.

Firmasari, S., \& Pramuditya, S. A. (2018). Desain bahan ajar analisis real dengan taksonomi solo dilengkapi soal-soal bentuk superitem. Jurnal Elemen, 4(1), 20-33. https://doi.org/10.29408/jel.v4i1.502.

Hestenes, D. (1991). The design of linear algebra and geometry. Acta Applicandae Mathematica, 23(1), 65-93. https://doi.org/10.1007/BF00046920.

Hidayat, W., \& Sari, V. T. A. (2019). Kemampuan berpikir kritis matematis dan adversity $\begin{array}{llll}\text { quotient } & \text { siswa } & \text { SMP. Jurnal }\end{array}$ https://doi.org/10.29408/jel.v5i2.1454.

House, J. D., \& Telese, J. A. (2012). Effects of mathematics lesson activities and computer use on algebra achievement of eighth-grade students in the United States and Japan: Findings from the TIMSS 2007 assessment. International Journal of Instructional Media, 39(1).

Jupri, A., Drijvers, P., \& van den Heuvel-Panhuizen, M. (2014). Difficulties in initial algebra learning in Indonesia. Mathematics Education Research Journal, 26(4), 683-710. https://doi.org/10.1007/s13394-013-0097-0.

Maarif, S. (2016). Improving junior high school students' mathematical analogical ability using discovery learning method. International Journal of Research in Education and Science, 2(1), 114-124. https://doi.org/10.21890/ijres.56842.

Malihatuddarojah, D., \& Prahmana, R. C. I. (2019). Analisis kesalahan siswa dalam menyelesaikan permasalahan operasi bentuk aljabar. Jurnal Pendidikan Matematika, 13(1), 1-8. https://doi.org/10.22342/jpm.13.1.6668.1-8.

Maudy, S. Y. (2015). Desain didaktis untuk mengatasi learning obstacle topik persamaan linear satu variabel. Disertasi tidak dipublikasikan, Bandung, Universitas Pendidikan Indonesia.

Morsanuto, S., \& Cipollone, E. (2019). The importance of "Unstructured" didactics in teacher training to improve the development of cognitive skills in children. Giornale Italiano di Educazione alla Salute, Sport e Didattica Inclusiva, 3(2), 8-21.

Mulyani, A., Indah, E. K. N., \& Satria, A. P. (2018). Analisis kemampuan pemahaman matematis siswa SMP pada materi bentuk aljabar. Mosharafa: Jurnal Pendidikan Matematika, 7(2), 251-262. https://doi.org/10.31980/mosharafa.v7i2.24. 
NCTM. (2000). Principles and standards for school mathematics. Reston, VA: The National Council of Teachers of Mathematics, Inc

Noto, M. S., Pramuditya, S. A., \& Fiqri, Y. M. (2018). Design of learning materials on limit function based mathematical understanding. Infinity Journal, 7(1), 61-68. https://doi.org/10.22460/infinity.v7i1.p61-68.

Noto, M. S., Pramuditya, S. A., \& Handayani, V. D. (2020). Exploration of learning obstacle based on mathematical understanding of algebra in junior high school. Eduma: Mathematics Education Learning and Teaching, 9(1), 14-20. https://doi.org/10.24235/eduma.v9i1.5946.

Palpialy, J. J. (2016). Pengembangan Desain didaktis materi pecahan pada sekolah menengah pertama (SMP). Disertasi tidak dipublikasikan, Bandung, Universitas Pendidikan Indonesia. https://doi.org/10.24198/jmi.v11.n2.9425.127-136.

Piaget, J. (1971). The theory of stages in cognitive development. In D. R. Green, M. P. Ford, \& G. B. Flamer, Measurement and Piaget. New York: McGraw-Hill.

Poon, K. K., \& Leung, C. K. (2010). Pilot study on algebra learning among junior secondary students. International Journal of Mathematical Education in Science and Technology, 41(1), 49-62. https://doi.org/10.1080/00207390903236434.

Pratiwi, V., Herman, T., \& Lidinillah, D. A. M. (2017). Upper elementary grades students'algebraic thinking ability in Indonesia. International E-Journal of Advances in Education, 3(9), 705-715. https://doi.org/10.18768/ijaedu.390554.

Prasetyo, A. Y. (2014). Ilustrasi buku cerita fabel sebagai media pendidikan karakter anak. Journal of Visual Arts, 3(1), 2252-7516.

Purwasih, R. (2015). Peningkatan kemampuan pemahaman matematis dan self confidence siswa MTs. di Kota Cimahi melalui model pembelajaran inkuiri terbimbing. Didaktik, 9(1), 16-25. Diambil dari http://ejournal.stkipsiliwangi.ac.id/index.php/didaktik/article/view/113

Putra, R. W. Y., Nurwani, N., Putra, F. G., \& Putra, N. W. (2017). Pengembangan desain didaktis bahan ajar materi pemfaktoran bentuk aljabar pada pembelajaran matematika SMP. NUMERICAL: Jurnal Matematika Dan Pendidikan Matematika, 1(2), 97-102. https://doi.org/10.25217/numerical.v1i2.133.

Putri, M. A., \& Haerudin, H. (2020). Kemampuan kognitif matematika ditinjau dari karakteristik kepribadian Keirsey. Prosiding Sesiomadika, 2(1a). Diambil dari https://journal.unsika.ac.id/index.php/sesiomadika/article/view/2382.

Rahayu, S. (2016). Analisis kesalahan siswa dalam menyelesaikan soal-soal kesebangunan. Jurnal e-DuMath, 2(1), 1-9. https://doi.org/10.21580/phen.2012.2.1.419.

Rohman, A. (2016). Pembiasaan sebagai basis penanaman nilai-nilai akhlak remaja. Nadwa, 6(1), 155-178. https://doi.org/10.21580/nw.2012.6.1.462.

Rosita, C. D., Nopriana, T., \& Silvia, I. (2019). Design of learning materials on circle based on mathematical communication. Infinity Journal, 8(1), 87-98. https://doi.org/10.22460/infinity.v8i1.p87-98.

Stapleton, L., \& Stefaniak, J. (2019). Cognitive constructivism: Revisiting Jerome Bruner's influence on instructional design practices. TechTrends, 63(1), 4-5. https://doi.org/10.1007/s11528-018-0356-8.

Suratno, T. (2016). Didaktik dan didactical design research. dalam Suryadi, D., Mulyana, T. Suratno, T., Dewi, D. A. K \& Maudy, S. Y (Eds), Monograf Didactical Design Research. Bandung: Rizqi Press.

Suryadi, D. (2013). Didactical design research (DDR) to improve the teaching of mathematics. Far East Journal of Mathematical Education, 10(1), 91-107. 
Suryadi, D., \& Nurlaelah, E. (2013). Desain didaktis konsep garis singgung lingkaran pada pembelajaran matematika sekolah menengah pertama (SMP). Jurnal Online Pendidikan Matematika Kontemporer, 1(1), 1-10.

Van den Heuvel-Panhuizen, M., Van Den Boogaard, S., \& Doig, B. (2009). Picture books stimulate the learning of mathematics. Australasian Journal of Early Childhood, 34(3), 30-39. https://doi.org/10.1177/183693910903400305. 